\title{
The relationship between students' second language learning anxiety and language proficiency
}

\author{
Asnadia Binti Alias ${ }^{1}$ Nur Atikah Binti Noor Rashid ${ }^{2}$ \\ ${ }^{1}$ Politeknik Sultan Mizan Zainal Abidin \\ ${ }^{2}$ Kolej Komuniti Kota Tinggi
}

\begin{tabular}{l} 
Article Info \\
\hline Article history: \\
Received Dec $3^{\text {rd }}, 2018$ \\
Revised Dec $4^{\text {th }}, 2018$ \\
Accepted Dec $8^{\text {th }}, 2018$ \\
\hline
\end{tabular}

\section{Keyword:}

Language anxiety Second language learning Language proficiency Polytechnics

\begin{abstract}
Students in Malaysian Polytechnics must enrol in a second language course as one of the compulsory courses offered by the institution. There is no placement test for polytechnics students to enrol in English language class. Therefore, students with different level of proficiency are mixed together in a classroom to learn English language. Consequently, students encountered difficulties in learning the second language due to feeling of anxiety. Hence, the aim of this study was to determine the correlation between students' language learning anxiety and their language proficiency. This study involved of 96 semester three students from Civil Engineering Department, Politeknik Sultan Mizan Zainal Abidin which have been chosen randomly. A 33 item questionnaire of Foreign Language Classroom Anxiety Scale (FLCAS) was analysed using SPSS 22. The study revealed that the students experienced moderate level of language learning anxiety. Correlations - Spearman Test was used to determine the relationship between students' second language learning anxiety and language proficiency. Three types of anxiety was tested which are Test Anxiety, Communication Apprehension and Fear of Negative Evaluation. Correlations - Spearman Test demonstrated that only Test Anxiety showed significant relationship with students' language proficiency. Several implications have been discussed to offer suggestions to the lecturers in dealing with students learning anxiety. Lecturers should be careful in correcting students' error to avoid students feel humiliated. This is because students tend to feel anxious whenever lecturers correct their mistakes in the classroom. A further research should be carried out by using two approaches; qualitative and quantitative and adds more variables such as attitude and motivation towards learning a second language.
\end{abstract}

(C) 2018 The Authors. Published by Redwhitepress.

This is an open access article under the CC BY-NC-SA license

(https://creativecommons.org/licenses/by-nc-sa/4.0/

\section{Corresponding Author:}

Asnadia Binti Alias,

Politeknik Sultan Mizan Zainal Abidin

Email: asnadia@psmza.edu.my

\section{Introduction}

\section{Background of the Study}

Anxiety plays a vital role especially in second language learning environment. Anxiety reflects the feeling of uneasiness, worried and fearful that leads to negative impact in human's feeling.According to Tobias \& Everson (1997), anxiety can be described as a complex concept that concerning one's feeling of self-efficacy, appraisal towards potential and perceived threats that are essential in certain situations. Therefore, the feeling of anxiety when communicating in a second language, to be exact in English language, may have a devastating effect towards the students which influence their adaptation on the target environment and most likely, their goal in education. The students may feel frustrated and experiencing low self-esteem when 
communicating with others in English due to the language learning anxiety. This reflects the situation in Malaysia especially in polytechnics setting, as the English course syllabus is integrated with the technical context.

Polytechnics are recognized as one of the prominent institution which offers technical and vocational educations in Malaysia. Throughout the years, polytechnics have going through many changes in order to keep up with the demand of various sectors of semi-professional employees, for instances in commerce, engineering and other service sectors. This is to be in line with the era of globalization and to ensure the ability to create manpower that meet the industry's demand and able to become reputable entrepreneur. This is also to guarantee that the polytechnics' students are marketable in the job prospect and able to apply the skilled learnt for their future employment. According to Janemary \& Melor (2016) "the English curriculum for primary schools is designed to provide learners with a strong foundation in the English language". In general, students in Malaysia experienced about 11 years in school system with strong foundation in English language since primary school and extensively learning English language in secondary school. Hence, the foundation supposedly enables the students to communicate fluently both while in the school and outside of school, in both written and oral form. Students who are able to communicate fluently in this language may have a lot of benefits. Students will have greater opportunity to pursue study in numerous of fields for instance engineering, medical, tourism and business study. Besides that, students also will get opportunity to have better employment.

English course in polytechnics is important because the syllabus design is integrated with the technical context. Students in Malaysian Polytechnics must enrol in a second language course as one of the compulsory courses offered by the institution. As per entry requirement in polytechnics, the students must at least pass in English and there is no placement test carried out for the students to enrol in English language course. Thus, there is a possibility of students with different level of proficiency are mixed together in a classroom. The students need to be able to use the English language in their daily communication. This is to ensure that the language will not be a reason of their future unemployment. As an individual, the students may go through different experiences while learning the second language. For instances, some students may have to deal with different language learning difficulties such as the feeling of anxiety, lack of motivation, lack of exposure and insufficient materials provided by the educators or institutions. Therefore, according to (Horwitz, Horwitz, \& Cope, 1986; MacIntyre \& Gardner, 1991; 1994), a number of researches shown that many students faced difficulties in learning a second language due to language anxiety and it is one of the affective factors that lead to low performance in second language among the learners.

The main purpose of English course in Polytechnics is to ensure students are able to communicate effectively and confidently. Nevertheless, numerous researches have revealed many students faced difficulties in learning a second language due to language anxiety (Horwitz, et al., 1986; MacIntyre \& Gardner, 1991; 1994). Mustafa Naci Kayaoğlu \& Hasan Sağlamel, (2013)in their studywas proposed several possible causes of language anxiety in speaking classes in their study such as linguistic difficulties, cognitive challenges, lack of info in the L1, competitiveness and the role of the teachers. The anxious students tend to overestimate their proficiency level and attempt to withdraw from interaction and situation that actually might help them to increase their proficiency level. Therefore, suitable ways to cater language learning anxiety among the students need to be identified in order to help the learner to be successful language user, especially in second language learning.

\section{Statement of the Problem}

The level of language proficiency among polytechnic students has become an arising issue nowadays. In a study conducted by Ahmad Yasruddin et al. (2010) revealed that Civil Engineering students of Politeknik Kota Bharu possess low level of frequency and/or ability of using the English language regardless of their level of study. The reason for this issue might be due to lack of exposure of using English language in their daily conversations. The results proven that the students are reluctant to communicate in English and many of them choose to withdraw from participating in any English language activities.

Furthermore, polytechnics introduce new syllabus which focuses more on Communicative Skills for the students. The syllabus emphasizes the uses of English language in both written and oral communication based on technical contexts. The new syllabus exposes the students on how to communicate effectively, to describe about products and services, job hunting skills and to do oral presentation. Besides that, the assessments carried out in polytechnics are varieties in both forms; oral and written whereby the students need 
to work in a team for group work assessment and also work as an individual for individual assessment. This is very challenging for some students as they are not fully equipped with the relevant skills to communicate effectively to complete the task, thus this may serve as a drawback for them in completing the task given. This may be seen as a result of their poor performance in English language.

Moreover, as a technical and vocational institution in Malaysia, learning English as a second language in polytechnics makes it more challenging factor for the students who are not proficient in English language. Students will have to learn new technical aspects for their courses, which using English language as a medium of instruction. The content of the technical courses itself is challenging because the students will encounter with many new vocabularies and jargon words. Students with low proficiency level might face difficulties in order to understand the language and at the same time mastering the content of the course.

\section{Rationale of the Study}

Generally, this study was aimed to determine the correlation between students' language learning anxiety and their language proficiency. This enables students, lecturers and institution to have useful information about language learning anxiety among students. For the lecturers, this study might be useful to identify students' language learning anxiety in learning a second language. As a result, it can help lecturers to design effective teaching methods to reduce language learning anxiety and also to create less stressful learning atmosphere in a classroom. In addition, lecturers can help students by giving appropriate solutions or suggest any possible ways of learning strategies to overcome the problem occurred. Therefore, it is hope that the students may perform well in learning a second language.

In addition, it is important for students themselves to be aware of their weaknesses in learning a second language and it may also help students to find out suitable strategies to overcome their anxiety problem. Furthermore, by conducting this study perhaps it may provide useful information for the institution in constructing appropriate language program to handle language learning anxiety problem among the students. Besides that, the institution may also provide appropriate materials and activities of second language learning in order to reduce anxiety among the students. This is fully supported by Yan and Horwitz (2008), in which by identifying the key factors and using relevant strategies to overcome the problem, language learning anxiety among the students might be reduced.

\section{Literature Review}

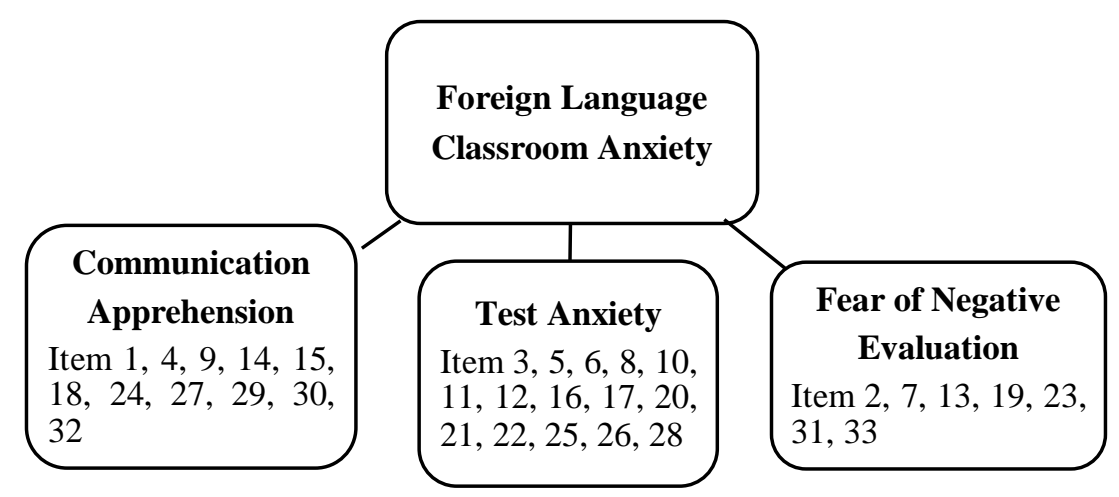

Figure 1: Model of Foreign Language Classroom Anxiety

This study is adapted a Foreign Language Classroom Anxiety model by Horwitz, Horwitz, and Cope (1986) to determine the correlation between students' language learning anxiety and their language proficiency. The model consists of three domains; Communication Apprehension, Test Anxiety and Fear of Negative Evaluation. There are many factors contribute to language anxiety among second language learners. According to Daly and Friedrich (1981), individual tends to be anxiety and apprehension if the individual is engaged in surrounding with apprehensive communication. Meanwhile, test anxiety occurs when students are worried of their results by the end of the study. Test in a second language study is essential to acknowledge the students' achievement at the end of the school year in order to measure students' progress of learning. In addition, Fear of Negative Evaluation is not only causing of fear of test evaluation but also happen in any 
social and evaluative situation such as job interview, oral presentation or speaking in foreign language in classroom.

According to Rebecca $(1990,164)$ "anxiety can play a strong role, short-circuiting potential learning in any of the four skills". Usually learners experience anxiety the most when speaking the new language. However, other skills such as listening, reading and writing the new language also lead them to experience remarkable anxiety. Four language skills which are listening, reading, speaking and writing are well known among language teachers and language learners. In learning a second language, learners are imposed to these language skills. In addition, grammar is also an important aspect in learning a second language. However, grammar is intersects and overlaps with listening, reading, speaking and writing. Rebecca $(1990,6)$ stated that "the term skill simply means ability, expertness, or proficiency". These skills are gained incrementally during the language develop.

Furthermore, Farah and Parilah (2012) conducted a study of 66 students of Malaysian University to determine kind and level of anxiety faced by Malaysian university. The study revealed that, oral presentation was the most stressful they have to deal with in a classroom setting followed by role play and answering teacher's question. On the other hand, for out of classroom setting, students have the most anxiety in having conversation with more than one native speaker followed by conversation with teachers and administrative staff in formal setting. Majority of the students demonstrated to have middle level of anxiety.

Interestingly, a study conducted by Pappamihiel (2002) regarding issues of English language anxiety in two settings; English as a second language and mainstream classrooms. The study conducted among 178 middle-school Mexican immigrant students attending school in the U.S. The data was collected by using English Language Anxiety Scale in order to analyse the difference between levels of English language anxiety in ESL and mainstream classes. The data also used to find out the relationship between levels of English language anxiety in ESL and mainstream classrooms in regard of time spent in the U.S., levels of academic achievement, listening and speaking skills, reading and writing skills and gender. Hence, the study also identified additional factors contributing to anxiety by using exploratory factor analysis. The result of the study indicated that English language anxiety levels among the students were increased more in the mainstream classroom compare to ESL classroom. It is suggested that those students experience anxiety in mainstream class because of the existence of native students who are very fluent in English language. The study also revealed that there were three factors significantly influence English language anxiety among the students which are level of achievement, reading and writing skills and gender. For the level of academic achievement, it showed that the increment in achievement level was lead to the declining of anxiety level in ESL classroom.In addition, students who believed they have good skills in reading and writing were less anxious than students who believed they were not good in those skills. In terms of gender, the study demonstrated female students were highly anxious when using the English language than male students. Overall, the result of this study suggested that English language anxiety is multidimensional, affecting ELL students differently depending on the context of the situation.

\section{Methodology}

This chapter describes the methodology that has been used to conduct the study. It begins with the discussion on the research design, setting, identification of the participants and adapted research instrument used for this study. Apart from that, it also presents the data collection and data analysis procedures throughout the research.

Before conducting this study, the researcher draws out a clear and systematic procedure. This is because a research design must consist of specific planning and data description (Kerlinger, 1970). With the reference of the conceptual framework of this study, it is clear that this study was used a quantitative research design by using a survey method. Thus, in order to identify language learning anxiety among the students, the researcher distributed a set of questionnaire to the participants consisting relevant information needed for this study. Questionnaire has been used in this study as the information on the particular data needed can be easily identified for the purpose of this study.

This study was carried out at Politeknik Sultan Mizan Zainal Abidin, whereby this institution is situated in Dungun, Terengganu. Currently, there are a total of 33 polytechnics altogether in Malaysia. Therefore, the 
main focus in this study was English Language Unit which plays a vital role to teach English language in polytechnics all over Malaysia.

The respondents consisted of 96 students of semester three from Civil Engineering Department of Politeknik Sultan Mizan Zainal Abidin. They enrolled in Communicative English Course and were selected based on a stratified random sampling method. This study was applied a stratified random sampling method in order to attain a sample that represents the whole targeted population (Tetteh, 2015). The respondents were chosen randomly based on the proportional that shared similar attributes and characteristics in the targeted population. The samples aged between 18 to 21 years old comprised of both male and female students at various level of proficiency from different socio-economic background. The background details of the respondents were obtained from responses provided in the questionnaire given.

In this study, a set of questionnaire was used to produce the end results. This questionnaire was consisted of two parts. The first part was Part A consisted the information of the respondent's background to obtain demographic data such as the respondent's name, gender, program, and Communicative English language result obtained in semester one. Meanwhile, the second part of the questionnaire was Part B adapted from the Foreign Language Classroom Anxiety Scale (FLCAS) by Horwitz et al. (1986). This part was included of 33 items, each on a 4-point Likert scale. The 4 point Likert scale ranged from Strongly Disagree (scale point 1), Disagree (scale point 2), and Agree (scale point 3), to Strongly Agree (scale point 4). Moreover, in FLCAS, there were three independent variables; Communication Apprehension, Test Anxiety and Fear of Negative Evaluation Anxiety.

For the purpose of this study, the questionnaire was distributed to a total of 96 respondents and administered by researcher herself during Communicative English period in the classroom. The researcher was conducted the survey by giving the instruction and explaining the purpose of the study to the respondents. After that, each of the respondents was given a set of the questionnaire and individually, they were asked to complete the answer by circling the most appropriate answer that relate to their experience and feeling regarding second language learning anxiety.

The data was gathered by the researcher straightly after the respondents have completed the questionnaire in the classroom. It is very crucial to collect the completed questionnaires at that particular time to avoid the possibilities of losing the data. In order to complete the set of questionnaire, each respondent took about 40 minutes to complete their responses.

The data gathered then was analyzed by using inferential statistics via SPSS (Statistical Package for Social Sciences) version 22. Correlation- Spearman Test was used to determine if there is a significance correlation between students' language learning anxiety to their proficiency level of English language.

\section{Results and Discussion}

\section{Respondents' Profile}

Table 1:Demography Profile

\begin{tabular}{cccc}
\hline Demography & Category & Frequency & Percent \\
Result & A & 22 & 22.9 \\
& A - & 8 & 8.3 \\
& B & 8 & 8.3 \\
B & 39 & 40.6 \\
B - & 7 & 7.3 \\
C + & 5 & 5.2 \\
C & 6 & 6.3 \\
D & 1 & 1.0 \\
& Total & 96 & 100.0 \\
\hline
\end{tabular}

Table 1 above shows the demographic profile of 96 respondents participated in this study. Majority of the respondents (40.6\%) scored grade B in Communicative English Course followed by (22.9\%) respondents 
scored grade A. Meanwhile grade A- and B+ scored by $8.3 \%$ respondents respectively for each category. $7.3 \%$ respondents scored grade $\mathrm{B}$-, followed by $6.3 \%$ respondents scored grade $\mathrm{C}$ and $5.2 \%$ respondents scored grade $\mathrm{C}+$. The lowest $(1.0 \%)$ scored by the respondents is grade $\mathrm{D}$.

\section{Descriptive Statistics}

Table 2: Mean and Standard Deviation of Language Learning Anxiety Level

\begin{tabular}{llll}
\hline Variable & $\mathrm{N}$ & Mean & Std. Deviation \\
Test Anxiety & 96 & 2.61 & 0.261 \\
Communication Apprehension & 96 & 2.72 & 0.222 \\
Fear of Negative Evaluation & 96 & 2.77 & 0.363 \\
\hline
\end{tabular}

Table 2 above shows the mean and standard deviation of anxiety level of each variable in this study, consists of Test Anxiety, Communication Apprehension and Fear of Negative Evaluation. The level of each variable was divided into three categories which are low, moderate and high. The result revealed that the mean value of 2.77 and a standard deviation of 0.363 for Fear of Negative Evaluation was the highest mean value and standard deviation compared to the other variables. This is followed by Communication Apprehension, mean value of 2.72 and a standard deviation of 0.222 . The lowest score was Test Anxiety, mean value of 2.61 and a standard deviation of 0.261 . Based on the result of the data analysis, the study indicated that the students' language learning anxiety level of the three variables consists of Test Anxiety, Communication Apprehension and Fear of Negative Evaluation can be categorized as moderate level of anxiety.

\section{Inferential analysis of correlation between language learning anxiety and students' language proficiency}

Research Question: Is there a significance correlation between students' language learning anxiety and their language proficiency?

Ha: There is a significant correlation between students' language learning anxiety and their language proficiency. The result of Correlation - Spearman test was shown as below:

Table 3: Correlations - Spearman Test between students' language

learning anxiety and students' language proficiency

\begin{tabular}{llll}
\hline Test & Variable & Result \\
\hline Spearman's rho & Test Anxiety & Correlation Coefficient & $0.269^{* *}$ \\
\cline { 2 - 4 } & $\begin{array}{l}\text { Communication } \\
\text { Apprehension }\end{array}$ & Correlation Coefficient & 0.008 \\
\cline { 2 - 4 } & $\begin{array}{l}\text { Fear of } \\
\text { Evaluation }\end{array}$ & Segative & 0.110 \\
& Correlation Coefficient & 0.287 \\
$* *$ Correlation is significant at the 0.01 level (2-tailed). & 0.138 \\
\hline
\end{tabular}

Table 3 above shows Correlation-Spearman test result between three variables which are Test Anxiety, Communication Apprehension and Fear of Negative Evaluation and students' language proficiency. The result demonstrated that Correlation value between language proficiency and test anxiety was $r=0.296$. It indicated that there was a negative correlation between language proficiency and Test Anxiety at $p<0.05$. The negative correlation indicates that the higher the level of Test Anxiety, the lower the language proficiency and the lower the level of Test Anxiety, the higher the language proficiency. However, there was no significant correlation between language proficiency and Communication Apprehension with $(r=0.110, p<0.01)$. Correlation between language proficiency and Fear of Negative Evaluation also showed similar result. There 
was no significant correlation between language proficiency and Fear of Negative Evaluation with $(\mathrm{r}=0.138$, $\mathrm{p}<0.01)$.

Based on the data analysis above, it can be concluded that only Test Anxiety was significantly correlate with language proficiency among Civil Engineering Students of Politeknik Sultan Mizan Zainal Abidin. Communication Apprehension and Fear of Negative Evaluation were not significantly correlates with students' language proficiency.

\section{Discussion}

The purpose of the study was to determine whether there was a significant correlation between language learning anxiety and language proficiency among Civil Engineering students. The study demonstrated that only Test Anxiety showed significant relationship between students' language learning anxiety and language proficiency. It implies that the higher the Test Anxiety, the lower the language proficiency and the lower the Test Anxiety, the higher the language proficiency. In addition, the assessments for Communicative English course consists of 50\% oral test, 30\% comprehension test and $20 \%$ listening test. Thus, it suggests that students encounter anxiety mostly during oral test such as oral presentation and role play. The students were concerned to make mistake in front of their classmate because they are not well competence in the language and this lead them to be more anxious and lack of confidence. Performing role play urges the students not only using the language but also need to express facial expressions and an appropriate body language. Language limitation might be the factors that lead the students to be more anxious while performing role play in front of their peers and lecturer. Overall, students are anxious of having bad test results compared to their peers. Besides that, the students also unease to use English in the classroom as the teacher will corrects their mistake directly in front of their peers. Students are afraid of being humiliated and others will underestimate their ability.

The finding of the study all together is consistent with the finding of study conducted by Ridha Fadillah (2010) which discovered that there was no significant relationship between English language proficiency and students' achievement in English as a foreign language. The study also revealed that there was a significance negative correlation between test anxiety and students' achievements. A study by Snyder (2011) revealed that there was no significant relationship between language learning anxiety and language competency among learners of public high school in Western New York. In terms of Test anxiety, the study demonstrated it was not significant correlate with language competency. It is in line with the finding of the study by Snezana et al. (2012) on 50 students from Macedonian University. The study revealed that the participants had moderate level of anxiety and there was no significant relationship between anxiety and participant's proficiency. Contrary, the study conducted by Comadena and Prusanka (1988) indicated that there was a significant relationship between students' academic achievement and Communication Apprehension. It is also supported by the study conducted by Von Wörde (2003) revealed that there was a significant negative correlation between anxiety and final foreign language grade. It is suggested that anxiety can negatively influence the language learning experience among the learners. Also, a study conducted by Awan et al. (2010) found similar finding which demonstrated that there was negative correlation between language anxiety and students' achievement. It indicates that as the level of anxiety increase, the academic achievement decrease.

\section{Conclusion}

The study intended to determine the correlation between language learning anxiety and students' language proficiency. Based on the results, it can be concluded that only Test Anxiety had significant relationship between students' language learning anxiety and students' language proficiency. Lecturers should play a major role in order to help students to overcome this problem. Thus, lecturers should be delicate and creative in order to make correction of the students' mistake in the classroom without humiliate the students. Moreover, the finding of this study also revealed that the students were experienced language learning anxiety in moderate level. Hence, an appropriate and meaningful action should be taken to reduce their anxiety level. The most important thing that lecturers can do is by creating less threatening environment in a classroom and inspires the students to have fun in learning English. The students must feel comfortable during the lesson so that students can learn better. Therefore, lecturers should be creative and vary their teaching methods to cater the students' preference and need. This is supported by Snyder (2011), whereby he emphasized that stress-free and calm learning atmosphere is very crucial to reduce students' level of anxiety. 
Furthermore, policy makers and curriculum designer should design an extensive English learning program that cater students' problem in terms of psycholinguistics aspect. Policy makers and curriculum designer need to give further consideration on language learning difficulties and challenges face by the students. These aspects are very important and equal to the other aspects of language learning difficulties such as language literacy. Besides that, a further research should be conducted in a large scale because this study only focuses on semester three students from Civil Engineering Department, Politeknik Sultan Mizan Zainal Abidin. Thus, the finding on this study cannot be generalized of the other students in other polytechnics. Apart from that, in order to get better results for future study, the method of study should be conducted in mix mode; qualitative and quantitative. Interview methods seem an ideal way to get useful information regarding the issues with in depth understanding instead of having questionnaire solely. By using two approaches, the process of analysis from the minor approach can support the analysis process of major approach. Last but not least, instead of having three variables which are Communication Apprehension, Test Anxiety and Fear of Negative Evaluation, another variable may be added such as students' attitude and motivation towards learning a second language.

\section{REFERENCES}

Ahmad Yasruddin Md Yasin, Wan Mohd Haniff Wan Mohd Shaupil, Affidah Mardziah Mukhtar, Noor Izma Ab Ghani \& Farawaheeda Rashid (2010). The English proficiency of Civil Engineering students at a Malaysian polytechnic. Asian Social Science. Vol. 6, No. 6.

Awan, R., Azher, M., Anwar, M. N., \& Naz, A. (2010). An investigation of foreign language classroom anxiety and its relationship with students' achievement. Journal of College Teaching and Learning, 7(11), 33-33-40.

Comadena, M., \& Prusank, D. (1988). Communication apprehension and academic achievement among elementary and middle school students. Communication Education, 32, 185-193. In Robert G. Powell \& Dana L. Powell (2010). Classroom communication and diversity: enhancing instructional practice. New York: Routledge.

Daly, J. A., \& Friedrich, G. (1981). The development of communication apprehension: A retrospective analysis of contributory correlates. Communication quarterly, 29, 243-255. In Robert G. Powell \& Dana L.

Powell (2010). Classroom communication and diversity: Enhancing instructional practice. New York: Routledge.

Farah Ayuni Ramlan \& Parilah Mohd Shah (2012). Second language anxiety among Malaysian university students. Bandung : Rizqi Press.

Janemary Thirusanku \& Melor Md Yunus (2016). The many faces of Malaysian English. Bangi: Universiti Kebangsaan Malaysia.

Horwitz, E. K., Horwitz, M. \& Cope, J. (1986). Foreign language classroom anxiety. The Modern Language Journal, 70(2), 125-132.

Kerlinger, F. N. (1970).A social attitude scale: Evidence on reliability and validity. Psychological Report, 26, 379-38

MacIntyre, P.D, \& Gardner, R.C. (1991). Methods and results in the study of anxiety in language learning: A review of the literature. Language learning, 41, 85-117. In Robinson, Peter(2002). Individual differences and instructed language learning. Amsterdam: John Benjamins Publishing Co.

MacIntyre, P.D., \& Gardner, R.C. (1994).The effects of induced anxiety on cognitive processing in computerised vocabulary learning. Studies in second language acquisition, 16, 1-17. In Robinson, Peter (2002). Individual differences and instructed language learning. Amsterdam: John Benjamins Publishing Co.

Mustafa Naci Kayaoğlu \& Hasan Sağlamel (2013). Students' perceptions of language anxiety in speaking Classes. Journal of History Culture and Art Research, Vol. 2, No. 2.

Pappamihiel, N.E. (2002). English as a second language students and English language anxiety: Issues in the mainstream classroom. Research in the Teaching Of English, Volume 36: The Florida State University.

Rebecca L. Oxford(1990).Language learning strategies: What every teacher should know. Wadsworth: Heinle \& Heinle Publishers.

Ridha Fadillah(2010). A study of adolescents' anxiety and achievement in English as a foreign language. Jurnal Ilmu Bahasa dan Sastera, Volume 5, No. 1.

Robert G. Powell \& Dana L. Powell (2010). Classroom communication and diversity: Enhancing instructional practice. New York: Routledge. 
Snezana Kirovaa, Biljana Petkovskaa, Dragana Kocevaa (2012). Investigation of motivation and anxiety in macedonia while learning English as a second/foreign language. Procedia - Social and Behavioral Sciences. 46, $3477-3481$.

Snyder, W.G. III. (2011). How anxiety affects second language acquisition of high school students.(Master's thesis). State University of New York at Fredonia.

Tetteh, E.D. (2015). Exploring the reasons for a failure of online educational portals in developing countries:Acase study of Koforidua polytechnic in Ghana. ASEAN Journal of Open Distance Learning.Vol. 7, No. 2.

Tobias, S., \& Everson, H. T. (1997). Studying Relationship between Affective and Metacognitive Variables. Anxiety, Stress, and Coping, 10 (1), 59-81.

Von Wörde, R. (2003). Students' perspectives on foreign language anxiety. Virginia Community College System.Volume 8, Number 1.

Yan, X. \& Horwitz, E.K. (2008). Learners' perceptions of how anxiety interacts with personal anD instructional factors to influence their achievement in English: A qualitative analysis of EFL learners in China. Language Learning, 58(1), pp. 151-183. 